\title{
ENVIRONMENTAL BALANCE OF SALT PRODUCTION SPEAKS IN FAVOUR OF SOLAR SALTWORKS
}

\section{V.M. SEDIVY}

Received: $19 / 08 / 08$

Accepted: 20/10/08

\author{
Salt Partners Ltd., Carl Spitteler Str. 102
}

$\mathrm{CH}-8053$ Zurich, Switzerland

*to whom all correspondence should be addressed: e-mail: vladimir.m.sedivy@salt-partners.com

\begin{abstract}
Solar saltworks are most efficient converters of solar energy into an inorganic commodity. Conversion rate of solar radiation into removal of water vapour from the brine takes place with $45 \%$ efficiency. Solar salt requires only a fraction of man made energy compared with salt produced by solution mining and thermal evaporation. Advanced technologies for biological management, crystallisation, harvesting techniques and salt processing, allow production of solar salt $99.94 \%$ pure, which is comparable with purity of vacuum salt.

Proper biological management of solar saltworks leads to brine containing less organics. Organic compounds in brine adversely influence the crystal growth habit, which results in inclusions of impurities inside the salt crystals. Advanced salt purification technology is able to completely remove impurities from the salt crystals incurring insignificant salt processing losses.

About $60 \%$ of salt produced worldwide is consumed by the chemical industry. High quality solar salt used as feedstock in membrane cell chloralkali plants causes equally low contaminated effluent discharge from brine treatment as vacuum salt. Trace elements that may cause membrane damage, such as iodine, or those elements that are critical to chlorine purity, such as bromine, are present in smaller quantities in solar salt than in many salts originating from rock salt deposits.

Bird watchers driving in jeeps through solar saltworks may not realise that the vast water fields hosting flamingos are not only beautiful but that they contribute towards the shift in the environmental balance in the direction of higher overall ecological benefit as well.
\end{abstract}

KEYWORDS: solar energy, biological management, Halobacterium, impurity inclusions, salt crystal habit, salt processing, salt losses, vacuum salt, membrane chloralkali cells, brine treatment.

\section{Salt production world-wide}

Recently, the annual world production of salt exceeded 200 million tons. More than one third of the total is produced by solar evaporation of sea water or inland brines. Another third is obtained by mining of rock salt deposits, both underground and on the surface. The balance is obtained as brines, mainly by solution mining. Brines can be used directly (for example in diaphragm electrolysis) or thermally evaporated to produce vacuum salt.

Table 1.

\begin{tabular}{lc}
\hline Salt type & World production \\
\hline Solar salt & $80,000,000 \mathrm{t} / \mathrm{y}$ \\
Rock salt & $60,000,000 \mathrm{t} / \mathrm{y}$ \\
Brines & $70,000,000 \mathrm{t} / \mathrm{y}$ \\
\hline
\end{tabular}

The purity of washed solar salt produced in India and China reach $99-99.5 \%$ ( $\mathrm{NaCl}$, dry bases) but solar salt produced in Australia and Mexico is $99.7-99.8 \%$ pure. Vacuum salt is usually 99.8 - 99.95\% pure. 


\section{SALT CONSUMPTION WORLD-WIDE}

The chemical industry is the largest salt consumer of salt using about $60 \%$ of the total production. This industry converts the salt mainly into chlorine, caustic soda and soda ash needed for petroleum refining, petrochemistry, organic synthesis, glass production, etc.

The second largest user of salt is mankind itself. Humans need about $30 \%$ of the total salt produced to support their physiological functions and eating habits. Salt for food is the most "taken for granted" commodity, available from thousands of sources in hundreds of qualities as table, cooking and salt for food production.

About $10 \%$ of salt is needed for road de-icing, water treatment, production of cooling brines and many other, smaller applications.

Table 2.

\begin{tabular}{lc}
\hline Salt user & Salt consumption \\
\hline Chemical industry & $60 \%$ \\
Food & $30 \%$ \\
Other & $10 \%$ \\
\hline
\end{tabular}

Whatever the use of salt, it is the sodium chloride in the salt that is required and not the impurities. The purer the salt, the more valuable it is.

\section{IMPURITIES IN NATURAL SALTS AND IN SOLAR SALTS}

Sodium chloride in salt is always the same. It is the "non-salt" in salt - the impurities - that make the difference. In fact, the multiplicity of impurities in salt and their relative quantities are so variable that every salt needs to be considered on its own merits.

Except for insolubles, the origin of impurities is the sea water. Solar sea salts, as a rule just few months old, are rather similar. Rock salts, millions of years old, may vary greatly, from pure to dirty, from white to black. Lake salts contain components leached from the ground of the surrounding rocks in variable quantities. Salt lake chemistry is a science of its own.

Calcium sulphate is the most persistent companion of salt. In rock salt, calcium sulphate is found as anhydrite, hemihydrite or polyhalite. Gypsum is found both in sea salt and in lake salt. Natural brines are, as a rule, saturated with calcium sulphate. Magnesium salts are always present in the sea salt, usually at a ratio of approx. one and a half weight units of magnesium chloride to one weight unit of magnesium sulphate. In lake salts, magnesium sulphate is usually accompanied by sodium sulphate, for example in Sambhar Lake salts from Rajasthan in India or in Azraq salts from Jordan.

Table 3.

\begin{tabular}{lcccc}
\hline & Rock salt & Sea salt & Lake salts & Brines \\
\hline $\mathrm{CaSO}_{4}$ & $0.5-2 \%$ & $0.5-1 \%$ & $0.5-2 \%$ & Saturated \\
$\mathrm{MgSO}_{4}$ & Traces & $0.2-0.6 \%$ & Traces & Traces \\
$\mathrm{MgCl}_{2}$ & & $0.3-1 \%$ & Traces & \\
$\mathrm{CaCl}_{2}$ & & & Traces & \\
$\mathrm{Na}_{2} \mathrm{SO}_{4}$ & & Traces & \\
$\mathrm{KCl}$ & Traces & Traces & Traces & Traces \\
$\mathrm{NaBr}$ & Traces & Traces & Traces & Traces \\
Insolubles & $1-10 \%$ & $0.1-1 \%$ & $1-10 \%$ & \\
\hline
\end{tabular}

Magnesium chloride also occurs together with calcium chloride, for example in the Dead Sea brines where also potassium chloride and sodium bromide are found in exceptionally high concentrations. Insolubles are present in salts of all origins in greatly fluctuating quantities.

\section{SALT PRODUCTION FROM BRINE BY VACUUM CRYSTALLISATION}

The highest standards of quality are set by vacuum salt. Usually, vacuum salt is produced from brine obtained by solution mining of underground deposits and chemically purified. Such brines are almost saturated, containing approx. $25 \% \mathrm{NaCl}$. Thus, to crystallise 1 tonne of salt, 3 tonnes 
of water need to be evaporated. In a six effect evaporation plant, 0.62 tonnes of live steam used six times do the job (Kondorosy, 2006). Assuming 10 bar steam, the heat transferred through steam condensation into the system is $390 \mathrm{kWh} \mathrm{t}^{-1}$ of salt. Assuming further that the steam boiler is generating steam with $75 \%$ efficiency, $450 \mathrm{kWh}$ of prime energy per tonne of salt is required.

\section{SALT PRODUCTION FROM BRINE BY MECHANICAL VAPOUR RECOMPRESSION}

Provided that electrical power is cheap, recompression of vapour from the evaporator in a radial compressor can be employed. The compressor elevates the vapour temperature to such a level that the vapour can condense in a heat exchanger against the circulating brine, bringing it to boil. This system uses about $160 \mathrm{kWh}$ of electricity per tonne of salt. Assuming $35 \%$ power generating efficiency, also approx. $450 \mathrm{kWh}$ of prime energy per tonne of salt is required in this system (Kondorosy, 2006).

Thermal evaporating plants (vacuum plants) and their operation are costly and so is the vacuum salt. Because it is crystallized from brine containing up to $4 \%$ of sulphate, vacuum salt always contains sodium sulphate, frequently some $200-500$ ppm or more. Despite the low calcium and magnesium content in the $1-10$ ppm range, vacuum salt will seldom exceed $99.95 \%$ purity.

\section{SALT PRODUCTION BY SOLAR EVAPORATION OF SEA WATER}

Sea water having density of $3.85^{\circ}$ Bè contains $30.09 \mathrm{~kg} \mathrm{NaCl} \mathrm{m}^{-3}$ and $998.64 \mathrm{~kg}$ of water (Baseggio, 1976). $89.9 \%$ of this water needs to be evaporated before the first crystals of $\mathrm{NaCl}$ can crystallise. Further $6.16 \%$ of water is evaporated before the brine becomes so concentrated that the evaporation slows down considerably, further evaporation would spoil the salt quality and therefore the brine (bitterns) need to be discarded, still containing $8.37 \mathrm{~kg} \mathrm{NaCl}$ per original $1 \mathrm{~m}^{3}$ of sea water. Thus $21.72 \mathrm{~kg}$ of $\mathrm{NaCl}$ can be recovered from $1 \mathrm{~m}^{3}$ of sea water by solar evaporation. Per each $1 \mathrm{~kg}$ of NaCl crystallised, $43.74 \mathrm{~kg}$ of water needs to be evaporated compared with $3 \mathrm{~kg}$ of water in thermal evaporation processes starting from almost saturated brine. Fortunately, solar energy is free of charge.

\section{EARTH'S SOLAR ENERGY BUDGET}

Virtually all energy available on the planet Earth originates from the sun (Mottershead, 2006). $26 \%$ of the incoming solar energy is reflected by atmosphere and by clouds back to space, $16 \%$ is absorbed by atmosphere, $3 \%$ absorbed by clouds and $4 \%$ is reflected from the surface. Thus $51 \%$ of the incoming solar energy reaches the surface and is absorbed by land, oceans and solar saltworks. $23 \%$ is converted into water vapour and is carried to atmosphere and to clouds in the form of latent heat of evaporation. The balance is returned to atmosphere by conduction and radiation and finally, all of the solar energy received from the sun is radiated back to space.

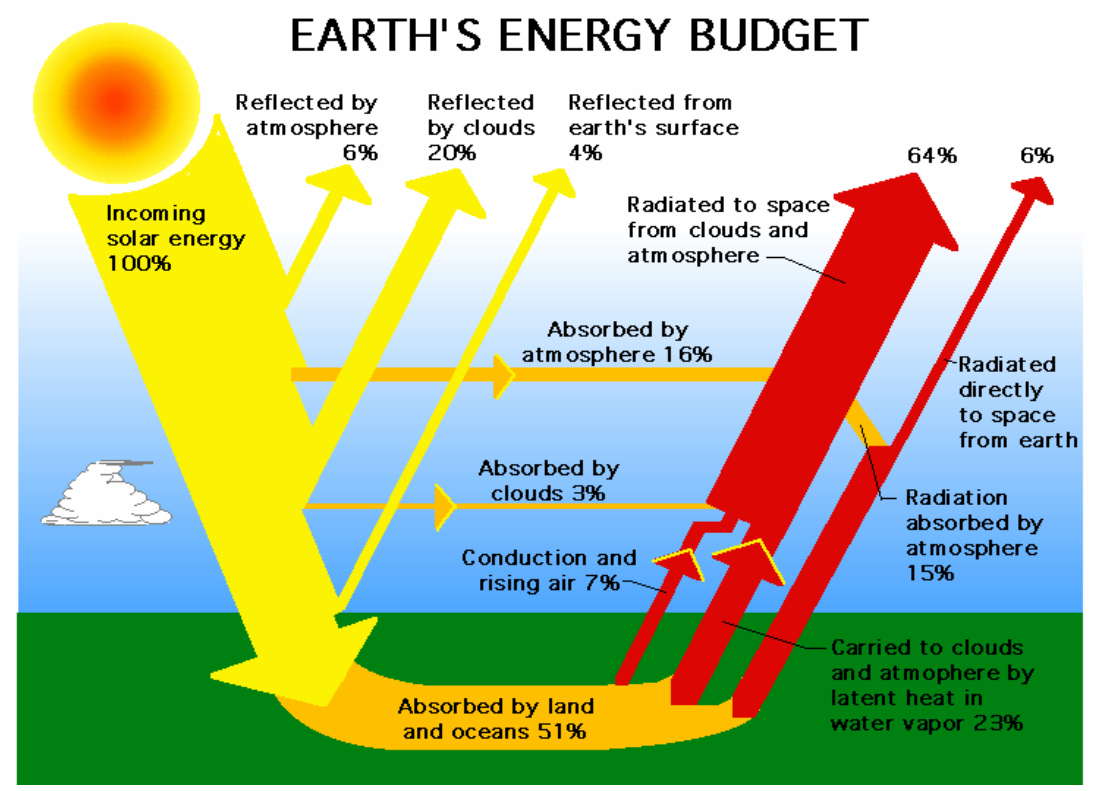

Figure 1. 
Relevant for the operation of solar saltworks is the $51 \%$ of the incoming solar energy that reaches the surface (surface insolation). It amounts to $51 \%$ of 1 ' $366 \mathrm{~W} \mathrm{~m}^{-2}+/-3.4 \%$ or $674-719$ $\mathrm{W} \mathrm{\textrm {m } ^ { - 2 }}$ when the sun stands in zenith. Averaged over 24 hours per day in sub-tropical zones where most of the solar saltworks are located, it corresponds to $200-300 \mathrm{~W} / \mathrm{m} 2$ daily radiation average. The absorbed solar energy is thus $5-7 \mathrm{kWh} \mathrm{m}^{-2} \mathrm{~d}^{-1}$.

Latent heat of water evaporation at $30^{\circ} \mathrm{C}$ is $0.675 \mathrm{kWh} \mathrm{kg}^{-1}$. Thus, $5-7 \mathrm{kWh} \mathrm{m}^{-2} \mathrm{~d}^{-1}$ of surface insolation, if absorbed completely, could evaporate $7-10 \mathrm{~mm}$ of water per day. However, winds not only carry away the water vapour from the saltworks area, they also cool the brine by heat conduction. This phenomena accounts for $7 \%$ of the absorbed heat. Another $15 \%$ is radiated to the atmosphere and $6 \%$ to the space. The balance, $23 \%$ of the insolation is converted into latent heat of water evaporation from brine, the ultimate driving force behind solar salt production. Thus, instead of $7-10 \mathrm{~mm}$ of water per day, only $3-5 \mathrm{~mm} \mathrm{~d}^{-1}$ or $1.1-1.8 \mathrm{~m} \mathrm{y}^{-1}$ is actually evaporated in average solar saltworks, resulting in production of $27-44 \mathrm{~kg} \mathrm{NaCl} \mathrm{m}^{-2} \mathrm{y}^{-1}$. In terms of salt layer in crystallisers, which represent about $10 \%$ of productive saltworks area, $270-440$ $\mathrm{kg} \mathrm{NaCl} \mathrm{m} \mathrm{m}^{-2}$ having a density of about $2 \mathrm{t} / \mathrm{m} 3$, forms a layer about $13-22 \mathrm{~cm}$ thick. Exceptions to this average are known to exist in areas with very high wind temperature, for example near deserts, when the hot air actually heats the brine by conduction, instead of cooling it. In those places, salt layer thickness of half a meter or so in a year can be formed.

Comparing the efficiency of solar energy conversion into final product, $23 \%$ out of $51 \%$ surface insolation is directly converted into salt, representing $45 \%$ conversion efficiency. This compares favourably with $8-15 \%$ conversion efficiency of photovoltaic cells, 30\% conversion efficiency of solar collectors with stirling engine and even with $40-45 \%$ efficiency of super critical steam power plants burning fossil fuels that incur additional $4-12 \%$ losses in the existing power distribution grids.

It is no exaggeration to claim that solar salt production is one of the most efficient uses of solar energy, just next to agriculture and forestry. Salt is mainly a basic inorganic chemical raw material. In the filed of inorganic chemistry, solar salt production is truly a remarkable and uniquely efficient process.

\section{PREJUDICE ABOUT SOLAR SALT}

Although several solar saltworks exist around the globe that produce excellent salt, many more produce salt having quality that leaves much to be desired. Thus, the general perception is that solar salt is cheap but dirty, impure, containing compounds that are detrimental to most of the uses, whether in the chemical industry, as food or anything else. Particularly in the chemical industry, in chlorine and caustic electrolysis or in soda ash manufacture, impurities in salt are costly and can be even dangerous.

\section{IMPURITIES IN SALT EFFECT THE CHEMICAL INDUSTRY}

In the chemical industry, salt is mostly dissolved together with the impurities in water or brine. Prior to feeding to the process, the brine is purified. Failure to purify the brine may have serious, even lethal consequences.

\section{Hydrogen evolution}

In electrolytic cells, excessive magnesium causes hydrogen evolution on the anode. Hydrogen and chlorine form an explosive mixture. Explosion in the cells or in the chlorine liquefaction may damage the equipment and release chlorine to the environment. Chlorine gas is highly poisonous. Stringent safety measures are taken in the chloralkali industry to avoid this to happen. The elimination of magnesium is of prime concern.

\section{Mercury butter}

Impure brine in mercury cells will cause butter formation. Butter will disturb mercury flow, causing short circuits that burn the electrodes. Alternatively, a large electrode gap must be maintained which will increase the power consumption. Butter removal will expose workers to mercury vapours that are damaging to health. Disposal of mercury butter is costly and undesirable for the environment. 


\section{Contaminated sludge}

Sludge from brine purification in chloralkali plants with mercury cells is contaminated with mercury. Sludge decontamination by distillation requires high temperatures, is costly and never complete. The disposal of mercury contaminated sludge is environmentally objectionable and very costly. Avoiding the formation of sludge is better than having to dispose of it. This requires salt of high purity.

\section{Membrane damage}

Calcium and magnesium will damage the ion exchange membranes irreversibly. Erratic impurity content in salt may cause hardness breakthrough to the membrane cells. Membranes cost a fortune. The purer the salt, the more remote is the danger of membrane damage.

\section{Encrustation}

In soda ash production, excessive sulphate reduces the value of the product. Accumulating calcium in the process causes encrustations. Periodical scale removal is costly and leads to loss of production.

Salt may be a cheap commodity. But impurities in salt and their removal cost in many cases more than the salt itself.

\section{HOW DOES THE CHEMICAL INDUSTRY DEAL WITH IMPURITIES IN BRINE?}

In the chemical industry, impurities in brine such as calcium and magnesium are precipitated with chemicals. In the chloralkali plants, sulphates are removed either by precipitation with barium or calcium or are controlled by purging the brine.

The main cost associated with brine purification is the cost of chemical reagents and the investment and operating cost of the brine treatment plants. In mercury cell plants, the cost of contaminated sludge disposal and purge decontamination is also substantial. In the membrane cell plants, the loss of salt in purge is much higher than in the mercury cell plants, reaching $30 \%$ with a salt feedstock containing some $0.7 \%$ of sulphate.

\section{THREE STEPS TO PRODUCE HIGH QUALITY SOLAR SEA SALT}

There are three main areas in the solar salt production process where the quality of the salt and the production yield is determined. Firstly, it is the brine pre-concentration area. The main task there is to increase the concentration of salts in the sea water from the starting density of $3.85^{\circ} \mathrm{Bè} \mathrm{to} 26^{\circ} \mathrm{Bè} \mathrm{when} \mathrm{NaCl}$ begins to precipitate. In this process, several requirements should be fulfilled:

- $\quad$ The sea water should increase its concentration gradually, without back-mixing.

- $\quad$ The sea water should not get lost due to seepage.

- The bottom of the ponds should be impervious (Davis, 1976) and dark, to facilitate maximum absorption of solar radiation.

- The sea water should remain clear, allowing solar radiation to reach the bottom of the ponds.

- Impurities, such as calcium carbonate and calcium sulphate, should crystallise to maximum possible extent prior to the brine reaching density of $26^{\circ} \mathrm{Bè} \mathrm{when} \mathrm{NaCl}$ begins to precipitate.

- Nutrients and biological material present in the feed sea water should be allowed to get consumed fully by succession of species whose life is supported by the respective salinity of the brine (Davis, 1976).

- The brine entering the crystallisers should be free of excessive organic material (Davis, 1979) that would negatively influence the salt crystallisation behaviour.

Secondly, it is the salt crystallisation area, where $\mathrm{NaCl}$ precipitates from brine progressing from density of $26^{\circ}$ Bè to $28.5^{\circ}$ Bè. The crystallisers should fulfil the following:

- $\quad$ The brine should not get lost due to seepage.

- The brine should support the existence of Halobacterium that colours the brine red, increasing the absorption of solar radiation. Halobacterium also oxidises organic matter (Davis, 1979) that is detrimental to salt quality. Organic matter is causing formation of fine, impure crystals and agglomerates with impurities trapped inside. Brine free of organic matter allows growth of large, clear and pure salt crystals. 
- The coloured brine layer should be thick enough to avoid reflection of solar radiation from the white salt crystals back to the atmosphere.

- The brine should proceed through the crystallisers without back-mixing, so that only $28.5^{\circ}$ Bè brine is drained, facilitating faster evaporation and avoiding contamination of salt with impurities, such as magnesium, sulphate, etc.

- $\quad$ Crystalliser dyke construction should prevent contamination of salt with insolubles.

- The harvesting method should recover maximum percentage of crystallised salt avoiding contamination with insoluble material at the bottom of the crystallisers.

Thirdly, it is the solar salt processing that purifies the salt prior to delivery. The purification process should fulfil the following requirements:

- $\quad$ Remove mother liquor from the salt crystals so that the salt crystal surface will be free of magnesium and sulphate impurities.

- $\quad$ Remove gypsum crystals and insoluble impurities from the salt so that the salt crystal surface will be free of calcium sulphate and insolubles and the salt will be white.

- $\quad$ Remove excess moisture from the salt so that no brine will drain from the salt during handling and storage, causing additional losses.

- $\quad$ Process the salt with minimum consumption of utilities, power and water and do so with minimum loss of sodium chloride.

$\bullet$

THREE COMPONENTS OF SUCCESSFUL SOLAR SALTWORKS DESIGN AND OPERATION The above requirements can be satisfied by:

- Firstly, correct solar saltworks design, taking into account the climatic and geological conditions, sea water quality and the mechanical design and operation of the saltworks (Mottershead, 2006)

- Secondly, solar saltworks as an open environmental system having its own life and metabolism of nutrients must be understood and correctly managed to achieve the goals of production capacity and quality of salt crystals, being large, hard, clear and pure inside (Davis, 1979)

- Thirdly, a salt purification process should be employed that purifies the salt crystal surface fully with minimum consumption of utilities and minimum of losses (Sedivy, 2006).

COMPARISON OF HIGH QUALITY SOLAR SALT AND VACUUM SALT

Australian salt is the best known and its quality is generally used as a standard. However, there are solar saltworks around the globe that employ advanced technologies and produce better salt than the famous saltworks in Australia. Australian standard compares with best solar salt and with vacuum salt, for example the salt produced in Switzerland, as follows:

Table 4.

\begin{tabular}{llccc}
\hline & & $\begin{array}{c}\text { Solar salt according to } \\
\text { "Australian Standard" }\end{array}$ & $\begin{array}{c}\text { Solar salt from most } \\
\text { advanced saltworks }\end{array}$ & $\begin{array}{c}\text { Vacuum salt from } \\
\text { Switzerland }\end{array}$ \\
\hline $\mathrm{Ca}$ & $\mathrm{ppm}$ & 400 & 100 & 5 \\
$\mathrm{Mg}$ & $\mathrm{ppm}$ & 200 & 50 & 1 \\
$\mathrm{SO}_{4}$ & $\mathrm{ppm}$ & 1200 & 300 & 300 \\
Insolubles & $\mathrm{ppm}$ & 20 & 20 & 20 \\
\hline $\mathrm{NaCl}$ & $\%$ & $99.7 \%$ & $99.94 \%$ & $99.95 \%$ \\
\hline
\end{tabular}

\section{SOLAR SALT UPGRADING}

Simple salt washing will remove some of the impurities. But the more you wash, the more you loose. So the question is: How to get higher purity with less losses? And still do it with enhanced overall economy?

Salt Partners devoted much time and effort to this subject (Sedivy, 1988; 1996). As a result, they developed a process that removes more impurities from salt, uses less water and recovers the dissolved salt to reduce the losses. If the salt is of poor quality and contains impurities inside the crystals, the process also removes them - by selectively cracking the crystals to free the enclosed impurities, with little formation of fines that increase the losses. The process achieves 
very high purity of $\mathrm{NaCl}$. It is known as the HYDROSAL salt upgrading process with HYDROEXTRACTION of impurities from SALT.

\section{PREDICTION OF SALT PURITY ACHIEVABLE WITH THE HYDROSAL PROCESS}

Even the best understanding of the principles of impurity formation and removal from salt cannot be transformed into a quantitative prediction of the achievable purity. This is only possible by testing the salt in the laboratory, using a sequence of unit operations that is identical to the sequence employed in the relevant process. Salt Partners have developed and standardized such procedure and used it to investigate hundreds of salt samples.

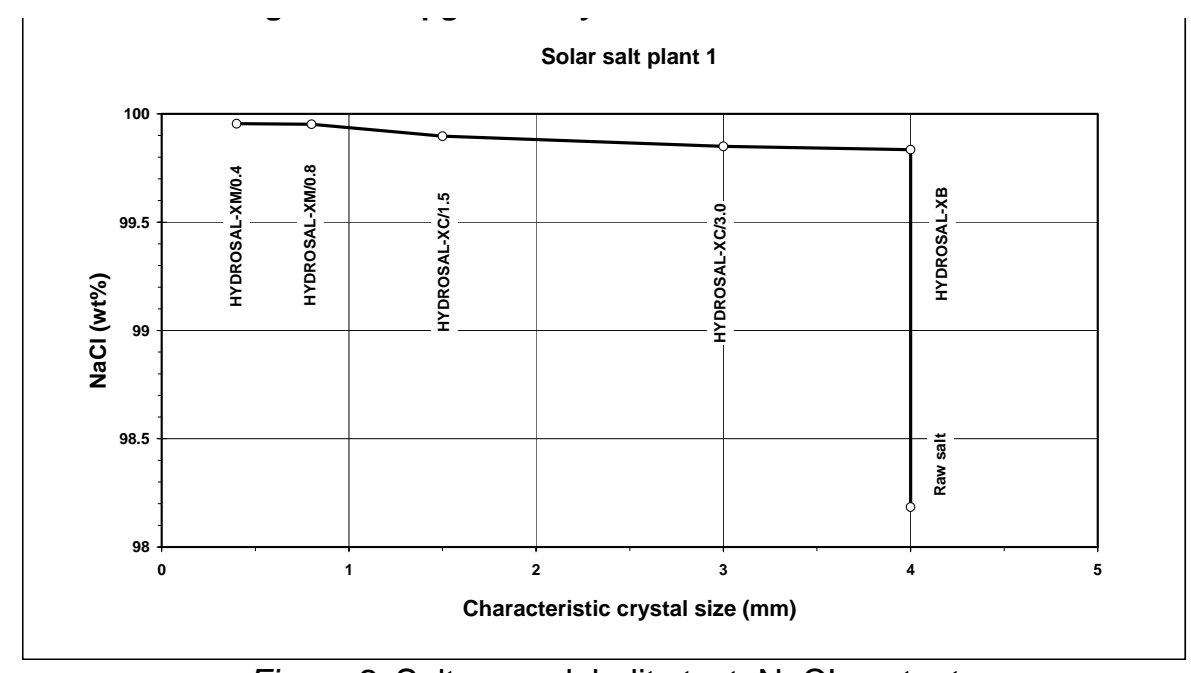

Figure 2. Salt upgradabality test, $\mathrm{NaCl}$ content

1. First, the raw salt is analysed. The raw salt analysis represents the sum of two unknown values: the surface impurities that are removable and those that are not. It is obvious that the raw salt analysis alone cannot give the information how much impurity can be removed and to what degree of purity the salt can be treated.

2. The next step is to find out, how much impurity can be removed without any change of the salt granulometry. This is called the HYDROSAL-XP upgradeability test.

3. Then we find out how much of the impurities enclosed inside the crystals can be removed if the salt is subjected to dry selective rupturing. Two characteristic crystal sizes, 1.5 and 3 $\mathrm{mm}$, have been established as a standard (HYDROSAL-XC/1.5 and HYDROSAL-XC/3 upgradeability test).

4. This is followed by a test with hydromilling (HYDROSAL-XM test). Here, 0.4 and $0.8 \mathrm{~mm}$ characteristic crystal sizes are used as a standard (HYDROSAL-XM/0.4 and HYDROSAL$\mathrm{XM} / 0.8$ refinability test).

5. If table salt production is intended, the HYDROSAL-XM salt is specially treated to produce salt that is blended with additives and analysed with respect to whiteness and free flowing characteristics. This is then called the HYDROSAL-XRT refined table salt test.

The analytical results are plotted against the characteristic crystal size. The resulting graphs are called the upgradeability curves, such as the one shown in Figure 1 above. The curves are produced separately for calcium, magnesium, sulphate and insolubles. The analysed impurities are stoichiometrically combined to calculate the sodium chloride content. Potassium chloride and sodium bromide are usually not considered as impurities. The results are summarized in a report. Samples from all tests are sent to the client and a second set is kept by Salt Partners for records. The test procedures and the analytical methods are given to clients who are encouraged to use them for control of their salt quality and the performance of their HYDROSAL plants. Thus, Salt Partners and their clients are able to refer to salt qualities and upgradabilities determined using consistent methodology over the years for the purpose of records, development or determination of plant performance guarantees. 


\section{PERFORMANCE OF THE HYDROSAL PROCESS}

Several salt upgrading plants with hydroextraction of impurities were built in Europe, in the Middle East and in India, many of them integrated in chloralkali plants. These plants process salt from solar saltworks, having $96-99 \% \mathrm{NaCl}$ content. The upgradeability of these salts varies widely. There are some excellent solar salts produced, but also some rather poor salts that are difficult to upgrade. The best upgradeable salts, such as the salt having upgradeability curve presented in Figure 1 above, are purified in the salt upgrading plants with hydroextraction of impurities to up to $99.8 \%$ purity. The best upgradeable salts are obtained in a THERMOSAL process (Sedivy, 2006) and upgraded to $99.988 \%$ purity, which is believed to be the record industrial salt purity ever achieved in Europe. The corresponding plant with hydroextraction of impurities works with certified purification efficiency of up to $97.4 \%$ and salt losses as low as $3.9 \%$.

\section{REFERENCES}

1. Baseggio, G. (1976) The composition of seawater and its concentrates, In: A. Coogan (Ed) Fourth Symposium on Salt: Volume 2, pp. 351-358. Northern Ohio Geological Society, Cleveland.

2. Davis J.S. (1976) Importance of Micro-organisms in Solar Salt Production, In: A. Coogan (Ed) Fourth Symposium on Salt: Volume 2, pp. 369-372. Northern Ohio Geological Society, Cleveland.

3. Davis J S., (1979) Biological Management of Solar Saltworks, In: Fifth International Symposium on Salt, Hamburg, Germany, pp. $265-268$.

4. Kondorosy E., (2006) Vacuum Salt Production by Using Various Processes, In: International Conference on Salt 2006, Ahmedabad January 2006.

5. Masuzawa T., (1979) Impurities Contained Inside the Crystals of Solar and Vacuum Evaporated Salts, In: Fifth International Symposium on Salt, Hamburg, Germany, pp. 463 - 473.

6. Mottershead R.A. (2006) Solar Salt - Optimising Production in India, China and Australia to Meet the Demand in Asia, In: International Conference on Salt 2006, Ahmedabad January 2006

7. NASA Homepage http://asd-www.larc.nasa.gov - not mentioned in the text

8. Sedivy V.M., International Seminar on Membrane Cell Technology, Vadodara 1988, The Processing of Solar Salt Feedstock for Membrane Cell Chloralkali Plants - not mentioned in the text

9. Sedivy V.M., Industrial Minerals, April 1996, Purification of salt for chemical and human consumption - not mentioned in the text

10. Sedivy V.M. (2000) Salt from hot air, Industrial Minerals, 40-45.

11. Sedivy V.M. (2006) Upgrading and refining of salt for chemical and human consumption , In: International Conference on Salt 2006, Ahmedabad January 2006.

12. Solar Stirling system ready for production (www.wapa.gov/es/pubs/esb/1998/98Aug/at solargen.htm) 